\title{
Use of Radiograph Optical Densitometry to Monitor Bone Quality in Broiler Breeders
}

\section{Author(s) \\ Almeida Paz $\mathrm{ICL}^{1}$ \\ Mendes $A^{2}{ }^{2}$ \\ Quinterio RR \\ Vulcano $\mathrm{LC}^{3}$ \\ Ballarin $\mathrm{AW}^{4}$ \\ Takahashi SE ${ }^{1}$ \\ Garcia $R^{1}$ \\ Komiyama $\mathrm{CM}^{1}$ \\ Balog $A^{5}$ \\ Pelícia $\mathrm{K}^{1}$ \\ Wescheler FS2 \\ Scudeller PSO $^{6}$}

Graduate student, Animal Science, Faculdade de Medicina Veterinária e Zootecnia, UNESP/Botucatu, SP, Brazil.

2 Professor, Departamento Produção e Exploração Animal, Faculdade de Medicina Veterinária e Zootecnia, UNESP/Botucatu.

3 Professor, Reprodução e Radiologia Veterinária, Faculdade de Medicina Veterinária e Zootecnia, UNESP/Botucatu.

4 Professor, Engenahria Rural, Faculdade de Ciências Agronômicas, UNESP/Botucatu.

5 Undergraduate student, Animal Science, Faculdade de Medicina Veterinária e Zootecnia, UNESP/Botucatu.

6 Graduate student, Veterinary Medicine, Faculdade de Medicina Veterinária e Zootecnia, UNESP/Botucatu.

\section{Mail Address}

Dr. Ariel Mendes

Faculdade de Medicina Veterinária e Zootecnia - UNESP

Departamento de Produção e Exploração Animal

Fazenda Experimental Lageado

18.618-000. Botucatu, SP, Brasil

E-mail: ibiara@fca.unesp.br arielmendes@fca.unesp.br

\section{Keywords}

Bone density, broiler breeders, eggshell quality, optical densitometry, Seedor index.

\section{ABSTRACT}

This study was carried out at Faculdade de Medicina Veterinária e Zootecnia, Universidade Estadual Paulista, Botucatu, SP, Brazil, and evaluated bone quality in broiler breeders. Twenty-three families of Ross broiler breeders were housed in $5.0-\mathrm{m}^{2}$ pens. The families were comprised of 13 females and one male at the onset of the experimental period. The mean number of females per family was 9.34 at the end of the trial. The feeding program and management followed strain guidelines (Agroceres Ross, 2003). Bone analyses were performed in the right tibia and femur using optical radiographic densitometry at 4, 8, 12, 15, 20, 24, $30,35,42,47$ and 52 weeks of rearing. Trap nests were used to collect eggs from the breeders two weeks before and after the evaluation weeks. At each evaluation day, five birds were sacrificed after radiographs were taken and the tibias and femurs were collected to perform the following analyses: fat-free dry matter, ash percentage, bone resistance and Seedor index. Therefore, it was possible to establish correlations between bone quality and eggshell quality. Characteristics of bone quality were highly correlated to each other; on the other hand, there were no correlations between bone quality and external egg quality. In conclusion, there was no effect of egg production on egg quality, possibly because there was no reabsorption of bone minerals.

\section{INTRODUCTION}

The poultry industry has employed up-to-date technology to rear birds. New knowledge has been constantly generated in order to produce healthier food at lower costs. Broiler breeder rearing is the division of the poultry industry that aims to produce fertile eggs of high quality, but also cost-effectively. Many factors contribute to the progress of the techniques and management practices used in this area. The most appropriate approach to obtain a highly viable production still seems to be caring for the interaction between genetics, nutrition, health and environmental conditions.

The breeding programs of broiler breeders have aimed the production of progenies with adequate body development and fast weight gain. This is one of the reasons why broiler production is currently the most important source of animal protein in Brazil (Rios et al., 2002). Nevertheless, the occurrence of abnormalities on the bone system such as tibial dyschondroplasia and necrosis of the proximal femur have caused economical losses. Therefore, an inexpensive and precise technique is needed to assess bone health by sequential analysis of bone mass changes. Optical radiographic densitometry is a biophysical technique of great experimental and clinical importance that might help to better understand and evaluate the bone mineralization process (Louzada, 1994). 
Almeida Paz ICL, Mendes AA, Quinterio RR, Vulcano LC, Ballarin AW, Takahashi SE, Garcia RG, Komiyama CM, Balog A, Pelícia K, Wescheler FS, Scudeller PSO

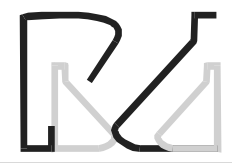

Use of Radiograph Optical Densitometry to Monitor Bone Quality in Broiler Breeders
Bones are part of the locomotion system. Some of the functions of bones include growth, support of the body weight, protection of inner organs, providing strength for muscle contraction and movement, mineral storage, and hematopoiesis (production of blood cells). Anatomically, bones are classified as long, short, flat or irregular. Long bones are comprised by the epiphysis (ends), physis (joint cartilage, epiphyseal cartilage and epiphyseal plate), metaphysis and diaphysis. The growth of long bones involves the radial growth of both epiphyses together with endochondral ossification and diaphysis ossification. Intramembranous growth occurs when bone tissue is deposited by osteogenic activity during epiphyseal growth. One of the most important structures in the study of bone growth after birth is the epiphyseal plate; the joint cartilage disappears after puberty and bone growth stops, although bone thickness still occurs (Macari et al., 1996, Macari et al., 2001).

Medullary bones such as the tibia suffer both deposition and bone reabsorption (bone loss). In broiler breeders, bone reabsorption might be less intense if diets with higher granulometry are fed, i.e., with large particles. Ingredients such as oyster meal are digested more slowly and extend the time of calcium supply directly from the gastrointestinal tract (Wilson et al., 1983; Julian, 2005). Nevertheless, adequate calcium supplementation in the diet might prevent bone reabsorption.

Eggshell integrity is important in the rearing of broiler breeders and even laying hens, since this structure is responsible for the protection of the egg contents. In broiler breeders, the eggshell is the most important barrier against contamination of embryos with pathogenic agents and guarantees healthy newlyhatched chicks. Eggshell quality might be assessed by variables such as specific gravity and eggshell porosity; quality is positively correlated with thickness and negatively correlated with the number of pores (Leesson \& Summers, 2000; Peebles \& Brake, 1987).

The objective of the present study was to evaluate the development of broiler breeders. Data on bone quality and external quality of the eggs was collected during the production period using low-cost and novel techniques. Correlations between eggshell quality and bone quality variables were also established.

\section{MATERIAL AND METHODS}

\section{Birds, housing and management}

This study was carried out using 280 female and 40 male breeders from the Ross 308 strain at the experimental poultry facilities of FMVZ - UNESP/ Botucatu. The birds were housed in a masonry poultry house divided into 24 pens of $5 \mathrm{~m}^{2}$ equipped with a black plastic screen ( $80 \%$ of light retention) and blackout curtains. Mean density was 2.6 birds per square meter. After 18 weeks of rearing, the black screen was removed and a total of 17 hours of light were provided per day by both natural and artificial lighting.

Until three weeks of rearing, infrared light brooders and initial hanging feeders were used. Afterwards, brooders were removed and feed was provided in troughs or adult hanging feeders. Feeding space was approximately $15 \mathrm{~cm}$ per bird. At ten days of age, all birds were debeaked using standard debeaking procedures.

Agroceres Ross guidelines (2003) were used as the basis for the feeding program and weight control. Daily feeding was used from 1 to 6 weeks of age and from 18 to 52 weeks of age. A 5-2 feeding program was adopted between 7 and 17 weeks of age (food is given in five days of the week), without calcium supplementation in the night-time.

During the initial and rearing phases, males and females were kept in separated pens. Afterwards, the birds were distributed into 24 pens $\left(2.8 \mathrm{birds} / \mathrm{m}^{2}\right)$ with 14 birds each; there were 22 pens with breeder families and reposition males were kept in the two remaining pens.

Egg analyses included egg weight, eggshell percentage and specific gravity. Samplings were performed using trap nests, which enabled individual egg production records. The eggs were collected two days before and after the radiographs were taken.

Nutritional levels in the diets were determined following the strain guidelines according to the rearing phases (Agroceres Ross, 2003), and males were fed separated from the females. Calcium granulometry was similar to that used in broiler feeding (smaller than 0.6 $\mathrm{mm})$.

\section{Radiograph optical densitometry}

Bone mineral density analyses were performed using the radiograph optical densitometry and the values were expressed in aluminum millimeters (Al $\mathrm{mm}$ ). Density was evaluated from 4 to 52 weeks of age (4, $8,12,15,20,24,30,35,42,47$ and 52 weeks). Eightyfour birds were randomly chosen to comprise the studied group; it was used 3 birds from 8 experimental pens and 4 birds from 15 pens.

Feed restriction was applied for 10 weeks (7 to 17 weeks of age). During this period, radiographs were 
Almeida Paz ICL, Mendes AA, Quinterio RR, Vulcano LC, Ballarin AW, Takahashi SE, Garcia RG, Komiyama CM, Balog A, Pelícia K, Wescheler FS, Scudeller PSO

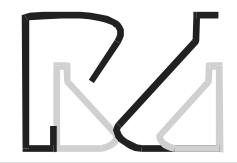

Use of Radiograph Optical Densitometry to Monitor Bone Quality in Broiler Breeders taken from the restricted birds. During the full-fed period, radiographs were taken from birds subjected to fasting.

Birds were individually weighed to the nearest $2 \mathrm{~g}$ and weight was recorded. Radiographs were taken at the Veterinary Hospital (FMVZ - UNESP/Botucatu) using a calibrated $X$-ray device placed at a focus-to-film distance of $63 \mathrm{~cm}$. All radiographs were taken using green $\mathrm{X}$-ray films from the same lot number that were placed in a cassette measuring $18 \times 24 \mathrm{~cm}$ and equipped with rare earth screens. A calibration aluminum wedge (phantom) was placed onto the cassette, $3.0 \mathrm{~cm}$ distant from the region that would be radiographed and parallel to it, to be used as a densitometry reference standard. The phantom comprises 20 steps measuring $15 \mathrm{~mm} \times 5 \mathrm{~mm}$. The first step is $0.5-\mathrm{mm}$ thick and thickness increases $0.5 \mathrm{~mm}$ at each step. Radiographs were taken using the $X$-ray device calibrated at $47 \mathrm{kVp}$ $X 2 \mathrm{~m}$ at 4,8 and 12 weeks and at $47 \mathrm{kVp} \times 4 \mathrm{mAs}$ afterwards.

Five birds were randomly chosen after radiographs were taken. These birds were killed and the legs were collected for analyses of bone resistance, bone ash percentage and Seedor index. The legs were dissected and the bones were frozen after identification. In the first sampling 84 birds were used (4 weeks of age), and this number was decreased at each sampling ( 5 birds per sampling day). On the last sampling at 52 weeks of age, 34 birds were sacrificed for bone quality analysis.

Optical density readings of the radiographs (bone mineral density) were performed using the software CROMOX ${ }^{\circledR}$ ATHENA 3.1 at standardized conditions. Briefly, radiographs were scanned and analyses were carried out using a reading window of $10 \mathrm{~mm}$ height and varying width (from 35 and $45 \mathrm{~mm}$ ) according to the bone size. A horizontal axis with $0^{\circ}$ of inclination was used. The inclination axis of the reading window was zero for tibia analyses and varied between $-27^{\circ}$ to $32^{\circ}$ for femur analyses, according to the inclination of the bone diaphysis.

\section{Seedor index, bone resistance, fat-free dry matter and ash percentage}

These variables were determined using the tibias and femurs collected from 5 birds on each sampling day. In the last sampling (52 weeks), 34 birds were sacrificed and the bones were sampled.

The Seedor index is obtained by dividing the bone weight by its length (Seedor, 1993) and the bone density might be inferred from it, i.e., greater indices indicate greater density. Measurements were taken using a caliper and a digital scale to the nearest $0.0001 \mathrm{~g}$.

Bone resistance was assessed in bones submitted to fat extraction with ethyl ether for 24 to 36 hours depending on the size of the bone. Analyses were performed at Departamento de Engenharia Rural, Faculdade de Ciências Agronômicas, UNESP/Botucatu. The analysis equipment (EMIC DL 10000) was calibrated to allow a 3-cm of diaphysis free space. This value was standardized for all bones, since it was the greatest free space possible to be used with the bone of smallest size. Standardization of the free space is necessary to allow the comparison of resistance ( $\mathrm{kgf}$ ) between bones.

Fat-free dry matter and ashes were performed using the same bones submitted to resistance analyses. Bone weight was recorded and the bones were dried for 72 hours at $60^{\circ} \mathrm{C}$. After cooling inside a desiccator, they were weighed again. The percentage of fat-free dry matter was calculated for each sampled bone (Bruno, 2002).

The samples were ground and 1-g sub-samples were taken to assess ash percentage. The sub-samples were placed in previously weighed porcelain crucibles and then in a muffle oven at $800^{\circ} \mathrm{C}$ for one hour. After cooling to ambient temperature inside a desiccator, the crucibles were weighed again and the percentage of ashes was calculated.

\section{Eggshell quality - specific gravity and eggshell percentage}

Eggshell quality was assessed using specific gravity and eggshell percentage according to Castelló et al. (1989). The evaluated eggs comprised eggs laid by the breeders from which bone quality was assessed, so that it was possible to establish correlations between eggshell quality and bone quality.

\section{Statistical analysis}

Statistical analyses were performed using the software SAEG (2003). Data were submitted to analysis of variance (ANOVA) and Tukey's test was used to compare means ( $5 \%$ ). Correlations were calculated using the test of Pearson at 5\% (Gomes, 1982). Curves of fatfree dry matter, ash percentage, Seedor index and bone resistance were adjusted by regression analysis.

\section{RESULTS AND DISCUSSION}

Bone mineral density values were obtained in vivo, whereas other results were obtained from bones sampled from slaughtered birds. 
Almeida Paz ICL, Mendes AA, Quinterio RR, Vulcano LC, Ballarin AW, Takahashi SE, Garcia RG, Komiyama CM, Balog A, Pelícia K, Wescheler FS, Scudeller PSO

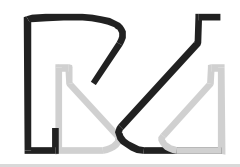

Use of Radiograph Optical Densitometry to Monitor Bone Quality in Broiler Breeders
Bone quality was assessed in tibias and femurs by means of bone mineral density (BMD), fat-free dry matter (FFDM), ash percentage, Seedor index and bone resistance. Eggshell quality was assessed by means of egg weight, eggshell percentage and specific gravity. Table 1 shows bone quality and eggshell quality results. Bone mineral density of the tibia and femur and the respective equation of linear regression are shown in Graph 1 and Graph 2.

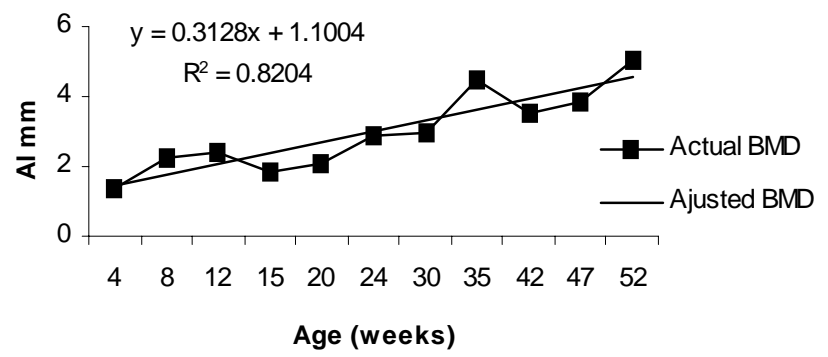

Graph 1 - Bone mineral density (mm Al) of tibias collected from broiler breeders.

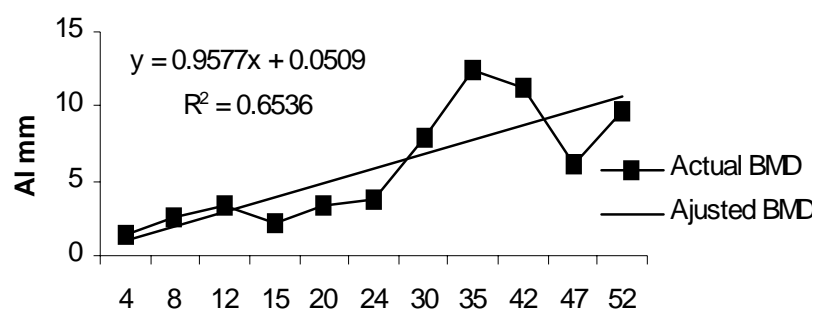

Age (weeks)

Graph 2 - Bone mineral density ( $\mathrm{mm}$ de Al) of the femurs collected from broiler breeders.

Age affected $(p<0.05)$ the evaluated variables. The values of bone quality increased with age, except for ash percentage.

BMD values in the tibia are similar to those reported in layers during the second laying period (Araújo et al., 2004). In this previous study, low sodium levels were used in the diet and the values of tibia BMD $(8.1 \mathrm{~mm}$ Al) are similar to those found in the femurs in the present study. These findings evidence that tibia and femur minerals have not been used for eggshell formation, because mineral deposition in the bones has occurred, except for a decrease in the femur density after 47 weeks of age, but these birds were not at maximum laying.

The values of fat-free dry matter, Seedor index and bone resistance were higher at 24 and 30 weeks of age, comprising both the pre-laying and early laying phases, since laying onset was at 27 weeks of age. Probably, there were high levels of ovarian hormones in the blood and the birds were preparing for production onset. Therefore, mineral requirements were increased, especially calcium requirements (Mahmoud et al., 1996; Agroceres Ross, 2000; Lesson \& Summers, 2000; Luquetti et al., 2002).

The Seedor index values were slightly smaller than in broilers. According to Bruno (2002), the values ranged between 17.03 and 87.46 in tibias and between 15.95 and 70.24 in femurs. Nevertheless, the author has also reported an increase in the values of Seedor index with increasing age.

The values of bone resistance are very similar to those reported in broilers aged between 42 and 53 days. Some authors have described values ranging between 9.24 and $19.61 \mathrm{kgf}$ in tibias and 9.51 and 20.31 kgf in femurs (Lott et al., 1980; Orban et al., 1993; Bruno, 2002).

Ash percentages are different from the results presented by Geraldo et al. (2004a) and Geraldo et al. (2004b). Diets containing finely ground limestone were used in these previous studies and ash percentages were reported to range between 57.08 and $58.61 \%$ in the tibias of 5-week-old rearing pullets (Lohmann-LSL) and between 58.23 and $59.77 \%$ in 12-week-old pullets. In the present study, similar results were seen between 30 and 35 weeks of age. On the other hand, Vilar da Silva et al. (2004) have reported values of ash percentage between 41.1 and $44.4 \%$ in bones of semi-heavy layers at 18 weeks of age. The values reported in the present study were higher and decreased with age; they were similar to the values found by Vilar da Silva et al. (2004) only at the end of the production cycle.

Correlations between the evaluated characteristics of bone quality are shown in Table 2. It was possible to observe that the bone quality characteristics were highly correlated between tibia and femur, except for bone resistance. Correlation was also high between the bone quality characteristics, except for bone resistance in the tibia, which was only correlated with bone mineral density of tibias and femurs. Ash percentage values showed a non-typical profile; negative correlations were found between ashes and $B M D$, Seedor index and fat-free dry matter.

Egg quality characteristics were correlated with few bone quality characteristics. Although egg weight showed slightly better correlations, the values were low. 
Almeida Paz ICL, Mendes AA, Quinterio RR, Vulcano LC, Ballarin AW, Takahashi SE, Garcia RG, Komiyama CM, Balog A, Pelícia K, Wescheler FS, Scudeller PSO

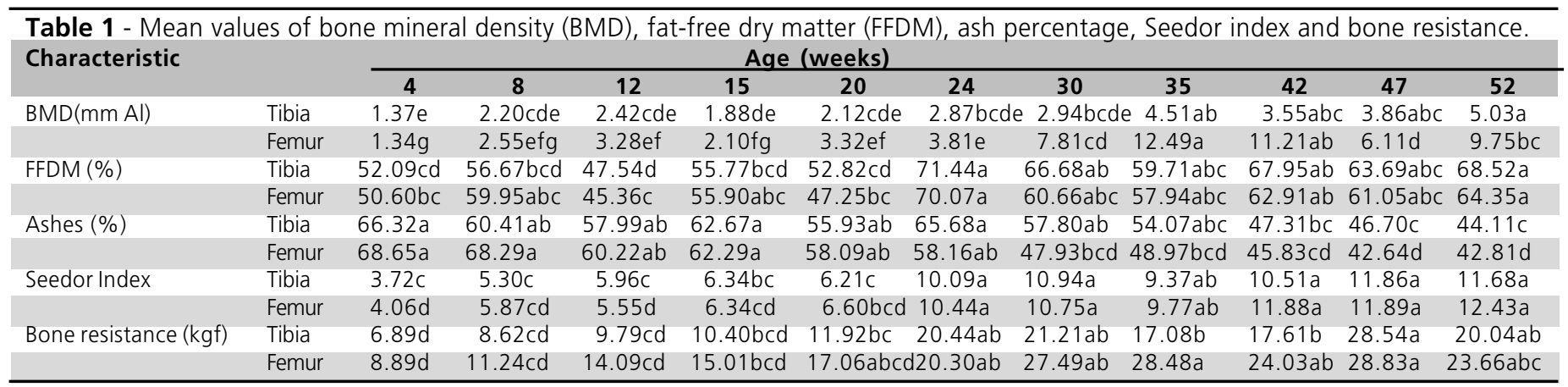

Means followed by different letters in the row indicate significant differences by the Tukey's test $(p<0.05)$. For FFDM, ashes, Seedor index, bone resistance, the mean values correspond to 5 tibias and 5 femurs per age, except for 34 tibias and 34 femurs at 52 weeks of age. For BMD, there are 84 birds at 4 weeks; 79 birds at 8 weeks; 74 birds at 12 weeks; 69 birds at 15 weeks, 64 birds at 20 weeks; 59 birds at 24 weeks; 54 birds at 30 weeks; 49 birds at 35 weeks; 44 birds at 42 weeks; 39 birds at 47 weeks; 34 birds at 52 weeks.

Table 2 - Correlation between fat-free dry matter (FFDM), ash percentage, Seedor index, bone resistance, and bone mineral density (BMD) in tibias and femurs of broiler breeders.

\begin{tabular}{|c|c|c|c|c|c|c|c|c|c|c|c|c|c|}
\hline & $\begin{array}{l}\text { FFDM } \\
\text { (tibia) }\end{array}$ & $\begin{array}{l}\text { Ashes } \\
\text { (tibia) }\end{array}$ & $\begin{array}{l}\text { Seedor index } \\
\text { (tibia) }\end{array}$ & $\begin{array}{c}\text { Resistance } \\
\text { (tibia) }\end{array}$ & $\begin{array}{l}\text { BMD } \\
\text { (tibia) }\end{array}$ & $\begin{array}{l}\text { FFDM } \\
\text { (femur) }\end{array}$ & $\begin{array}{c}\text { Ashes } \\
\text { (femur) }\end{array}$ & $\begin{array}{l}\text { Seedor index } \\
\text { (femur) }\end{array}$ & $\begin{array}{c}\text { Resistance } \\
\text { (femur) }\end{array}$ & $\begin{array}{c}\text { BMD } \\
\text { (femur) }\end{array}$ & $\begin{array}{c}\text { Egg } \\
\text { weight (g) }\end{array}$ & $\begin{array}{c}\text { Egg } \\
\text { shell\% }\end{array}$ & $\begin{array}{l}\text { Specific } \\
\text { gravity }\end{array}$ \\
\hline FFDM (tibia) & 1.00 & & & & & & & & & & & & \\
\hline Ashes (tibia) & -0.20 & 1.00 & & & & & & & & & & & \\
\hline Seedor index (tibia) & 0.83 & -0.47 & 1.00 & & & & & & & & & & \\
\hline Bone resistance (tibia) & $-*$ & - & - & 1.00 & & & & & & & & & \\
\hline BMD (tibia) & 0.32 & -0.38 & 0.53 & 0.44 & 1.00 & & & & & & & & \\
\hline FFDM (femur) & 0.88 & - & 0.73 & - & 0.27 & 1.00 & & & & & & & \\
\hline Ashes (femur) & -0.51 & 0.72 & -0.76 & - & -0.48 & -0.40 & 1.00 & & & & & & \\
\hline Seedor index (femur) & 0.83 & -0.48 & 0.95 & - & 0.49 & 0.79 & -0.76 & 1.00 & & & & & \\
\hline Bone resistance (femur) & 0.52 & -0.32 & 0.65 & - & 0.47 & 0.46 & -0.51 & 0.62 & 1.00 & & & & \\
\hline BMD (femur) & 0.35 & -0.30 & 0.58 & 0.43 & 0.67 & 0.23 & -0.46 & 0.50 & 0.44 & 1.00 & & & \\
\hline Egg weight & 0.38 & -0.34 & 0.33 & - & - & 0.24 & -0.38 & 0.20 & -0.31 & - & 1.00 & & \\
\hline Eggshell percentage & - & - & - & - & -0.15 & 0.23 & - & - & - & - & -0.45 & 1.00 & \\
\hline Specific gravity & 0.21 & - & - & - & - & 0.18 & - & - & - & - & 0.27 & 0.69 & 1.00 \\
\hline
\end{tabular}

Pearson correlation ( $5 \%$ of significance). Non-significant correlations are indicated by " -" and the values were not shown.

It may be inferred from such results that the birds did not use bone calcium from the tibias and femurs to produce eggshells. This is probably because bone calcium is used in eggshell production only when there is no availability of dietary calcium (Maggioni, 1998; Agroceres Ross, 2003; Julian, 2005). Apparently, this was not the case in the present study, even though fine limestone has been used and no calcium supplementation has been provided in the night-time.

\section{CONCLUSION}

The evaluated bones were denser and more resistant in older birds. The bone mineral contents increased with time, since it was not necessary to make them available for eggshell production.

\section{REFERENCES}

Agroceres Ross. Manual de manejo de matrizes. São Paulo: Agroceres Ross Melhoramento Genético de Aves; 2000. 76p.

Agroceres Ross. Manual de manejo de matrizes. São Paulo: Agroceres Ross Melhoramento Genético de Aves; 2003. 81p.
Araújo CSS, Baraldi-Artoni SM, Araújo LF, Junqueira OM, Laurentiz AC, Betioli MML. Densidade óssea em poedeiras comerciais no $2^{\circ}$ ciclo de produção. In: Conferência Apinco de Ciência e Tecnologia Avícolas; 2004; Santos, SP. Brasil. p. 139.

Bruno LDG. Desenvolvimento ósseo em frangos de corte: influência da restrição alimentar e da temperatura ambiente [dissertação]. Jaboticabal: Universidade Estadual Paulista; 2002.

Castelló JAC, Pontes MP, González FF. Producción de huevos. Barcelona, España: Real Escuela de Avicultura; 1989. 367p.

Geraldo A, Fssani EJ, Kato RK, Brito JAG, Mendonça MO, Bertechini AG. Níveis de cálcio e granulometria do calcário para frangas de reposição no período de 3 a 5 semanas de idade. In: Conferência Apinco 2004 de Ciência e Tecnologia Avícolas; 2004; Santos, SP. Brasil. p. 92.

Geraldo A, Brito JAG, Bertechini AG, Fassani EJ, Kato RK, Fialho ET. Níveis de cálcio e granulometrias do calcário para frangas de reposição no período de 3 a 12 semanas de idade. In: Conferência Apinco 2004 de Ciência e Tecnologia Avícolas; 2004b; Santos, SP. Brasil. p. 93.

Gomes FP. Curso de estatística experimental. Piracicaba: Ed. Nobel; 1982. 430p. 
Almeida Paz ICL, Mendes AA, Quinterio RR, Vulcano LC, Ballarin AW, Takahashi SE, Garcia RG, Komiyama CM, Balog A, Pelícia K, Wescheler FS, Scudeller PSO
Use of Radiograph Optical Densitometry to Monitor Bone Quality in Broiler Breeders
Julian RJ. Patologias ósseas em aves. In: Conferência Apinco 2005 de Ciência e Tecnologia Avícolas; 2005; Santos, SP. Brasil. P.107122.

Leeson S, Summers JD. Broiler breeder production. Guelph, Canada: University Books; 2000. 329p.

Lott BD, Reece FN, Drott JH. Effect of preconditioning on bone breaking strength. Poultry Science 1980; 59(4):724-25.

Louzada MJQ. Otimização da técnica de densitometria óptica em imagens radiográficas de peças ósseas. Estudo in vitro [tese]. Campinas: Universidade Estadual de Campinas; 1994.

Luquetti BC, Bruno LDG, Giacheto PF, Furlan RL, Gonzales E, Macari M. Influência da idade da matriz sobre características da casca e parâmetros sangüíneos e cardíacos de pintos neonatos. In: Conferência Apinco de Ciência e Tecnoligia Avícolas; 2002. Campinas, SP. Brasil. p.5.

Macari, M. Água na avicultura industrial. Jaboticabal: FUNEP;1996, $128 \mathrm{p}$.

Macari M, Furlan RL, Gonzales E. Fisiologia aviária aplicada a frangos de corte. 2. ed. Jaboticabal: FUNEP; 2001. 375p.

Maggioni R. Efeito do fracionamento de cálcio dietético sobre o desempenho produtivo e a qualidade da casca do ovo de poedeiras semi-pesadas durante o verão [dissertação]. Pelotas: Universidade Federal de Pelotas; 1998.

Mahmoud KZ, Bech MM, Scheideler SE, Forman MF, Anderson KP, Kadchman SD. Acute high environmental temperature and calciumestrogen relationship in the hen. Poultry Science 1996; 75(12): 1555-1562.

Orban JI, Roland SR, Bryant MM. Factors influencing bone mineral content, density, breaking strength, and ash as response criteria for assessing bone quality in chickens. Poultry Science 1993; 72(3):437-56

Peebles ED, Brake J. Eggshell quality and hatchability in broiler breeder eggs. Poultry Science 1987; 66:594-604.

Rios JNF, Zanella I, Bonato EL, Silva S, Scher FA. Avaliação de parâmetros produtivos de matrizes tipo corte recriadas com diferentes métodos restritivos para recuperar falhas de manejo. In: Reunião Anual da Sociedade Brasileira de Zootecnia [CD-ROM]; 2002; Recife:UFRPE; 2002.

SAEG (Sistema para análise estatística e genéticas). Manual de utilização do programa SAEG. Viçosa: UFV; 2003. 59p.

Seedor JG. The biophosphanate alendronate (MK-217) inhibit bone loss due to ovariectomy in rats. Journal of Bone and Mineral Research 1993; 4:265-270.

Vilar da Silva JH, Ribeiro MLG, Rocha MRF, Santos JL, Costa FGP, Barros LR. Efeito do fósforo disponível e da fitase sobre o desempenho, níveis de fósforo plasmático e teor de cinzas nos ossos de poedeiras semipesadas. In: Conferência Apinco de Ciência e Tecnologia Avícolas; 2004; Santos, SP. Brasil. p. 94.
Wilson HR, Ingram DR, Harms RH. Restricted feeding of broiler breeders. Poultry Science 1983; 62(7):1133-1141. 